\title{
Household-level predictors of the presence of servants in Northern Orkney, Scotland, 1851-1901
}

\author{
Julia A. Jennings ${ }^{\mathrm{a},{ }^{*}}$, James W. Wood ${ }^{\mathrm{b}, \mathrm{c}}$, and Patricia L. Johnson ${ }^{\mathrm{b}, \mathrm{c}}$ \\ aCarolina Population Center, University of North Carolina at Chapel Hill, CB\# 8120, University \\ Square, 123 W. Franklin St., Chapel Hill, NC 27516, USA \\ bDepartment of Anthropology, 409 Carpenter Building, Pennsylvania State University, University, \\ Park, PA 16802, USA \\ 'Population Research Institute, Pennsylvania State University, University Park, PA 16802, USA
}

\begin{abstract}
Servants were an important part of the northwestern European household economy in the preindustrial past. This study examines household-level characteristics that are predictive of the presence of rural servants using data from Orkney, Scotland. The number of servants present in a household is related to household composition, landholding size, and the marital status of the household head. In addition, the sex of the particular servant hired reveals that the labor of male and female servants is not fungible. The sex of the servant hired is related to the ratio of male and female household members of working age, the occupation of the head, household composition, and the size of the household's landholding.
\end{abstract}

\section{Keywords}

Historical demography; farm labor; servants; household economy; sexual division of labor; Orkney; Scotland

\section{Introduction}

\begin{abstract}
In preindustrial Northwest Europe, most farming was small scale and conducted by the members of a single household. Since households were composed primarily of closely related kin, farming was a family enterprise. However, families could supplement their domestic labor force by hiring farm workers, either by the day or task, or on a longer-term live-in basis. While all servants contribute to the family economy, live-in servants, who typically lodged with the farmer's family and ate from the same table, can be considered a close substitute for family labor, a resource that varies over the demographic life cycle of the farming family. Indeed, servants can be considered a supplement to household labor employed to ensure sufficient food and craft production and full use of the household's resources, such as land and livestock. Service can thus be viewed as part of an "adaptive
\end{abstract}

(C) 2010 Elsevier Inc. All rights reserved.

*Corresponding Author, Tel: +1 919-966-2578, Fax: +1 919-843-3630, julia.jennings@unc.edu. James W. Wood, Tel: +1 814-865-2509, Fax: +1 814-863-1471, jww3@psu.edu Patricia L. Johnson, Tel: +1 814-865-3129, Fax: +1 814-863-1471, plj2@psu.edu

Publisher's Disclaimer: This is a PDF file of an unedited manuscript that has been accepted for publication. As a service to our customers we are providing this early version of the manuscript. The manuscript will undergo copyediting, typesetting, and review of the resulting proof before it is published in its final citable form. Please note that during the production process errors may be discovered which could affect the content, and all legal disclaimers that apply to the journal pertain. 
family economy" as the practice provided flexibility to social, familial, and economic relationships and allowed households to diversify the employment of their members (Wall, 1986). Therefore, all other things being equal, it is hypothesized that the amount and quality of land to which a household has access, the size and composition of the household labor force, and the overall consumption requirements of the household will be important predictors of the number of servants a household hires. In addition, male and female labor is likely to be deployed differently, depending on the specific tasks a household must accomplish. Thus, the sex of the servant hired might also be predicted by household characteristics, including access to land, household age and sex composition, and household size, while controlling for other factors.

Data from the Orkney Islands, off the northern coast of mainland Scotland, provide an opportunity to contribute to the study of farm servants, domestic labor, and the sexual division of agricultural labor. Service employed many young people, moved people over the landscape, and was often an important component of the household economy of traditional farmers. Service in Orkney persisted throughout the study period, 1851-1901.1 Available historical sources provide information about individuals, households, and landholdings, making this dataset useful for examining the relationships among household composition, land resources, and the hiring of live-in servants. Hurdle models are used to help identify factors that influence both the number and sex of servants present in the household, after controlling for various household characteristics, including those related to the household head.

\section{Background}

\subsection{Definition of Servants}

Service in Western Europe was a diverse practice, encompassing both servants in husbandry (Kussmaul, 1981a) and domestic servants in urban settings (Fauve-Chamoux, 2004). Service as an occupation has also been identified with a period of young adulthood. "Life-cycle servants," described by Peter Laslett (1977, p. 34) worked as servants in the period between adolescence and marriage. For these individuals, service was a short-term occupation that provided useful training in agricultural and domestic tasks, but was not an apprenticeship or career (Goldberg, 1992; Whittle, 2000). Servants also varied in their place of residence. Some servants were employed on a live-in basis, and resided as members of the household of their employers, while others lived at home (typically their parent's household) and worked as servants during the day.

Live-in servants had a special role in the household economy of rural areas. They were provided room and board as well as a wage. The status of live-in servants was ambiguous; they might not be closely related to their master, yet they typically lived as part of their master's family, ate from the master's table, and were often described in familial terms (Kussmaul, 1981a, b).2 They were also wage earners, who were saving for marriage or sending remittances to their families. This particular function of service is a major tenet of what is often called the "Hajnal hypothesis" (Engelen \& Wolf, 2005) after the work of John Hajnal (1982). It proposes that, in Northwest Europe, there existed a normative requirement that a couple establish an independent household upon marriage. To do so, young people must inherit or earn, often through service, sufficient resources to set up a household of their

\footnotetext{
${ }^{1}$ The beginning of the study period coincides with the first census conducted in Orkney that included information suitable for record linkage (Sparks 2007); the end date is determined by the statutory 100-year embargo on the release of individual-level census returns in the UK.

${ }^{2}$ Much of the existing literature on servants seems to assume that master and servant were unrelated. However, it may be the case that servants often had kin ties to their masters. Future study using the Orkney data may be able to address the closeness and frequency of kin relationships in service arrangements.
} 
own. Hajnal (1982) suggests that late age at marriage together with the requirement for newly married couples to set up their own separate households kept rural populations in balance with their productive resources, especially land. This hypothesis combines the approaches of population history and family history (Oris, 2003). Service, in this view, can be approached from the perspective of both the rural and household economy. The demand and supply of servant labor is partly determined by local conditions, including the requirements of agricultural and non-agricultural rural employment. Another important determinant of the circulation of servants is variation in household-level conditions as local households had different labor pools and consumption requirements that varied with stages in the family life cycle, as well as differential access to land and other resources. Households that hire servants are in need of labor and are likely to have distinct characteristics from households that do not hire servants. Following this logic, the household will be used as the unit of analysis in the present study.

The sources used in this study can identify which households hired live-in servants. Servants are identified using the census variable "relationship to head", which indicates that these individuals were live-in servants, rather than people who lived in their own homes and worked as a "farm servant" for wages, either in full- or part-time capacity. In addition, livein servants are distinguished from people whose listed occupation was "farm servant," "agricultural servant," or "domestic servant." In Orkney, these were common occupations that were more permanent than day labor, but were often only part-time or seasonal. In other words, these individuals lived at home and worked at a nearby farm, but perhaps only during the planting or harvest seasons. These occupations are listed under the census heading "occupation" and their relationship to the head indicates familial (such as son or sister) relationships rather than employer-employee (servant) relationships. 3 The sources used in this study cannot identify which servants were temporary life-cycle servants, and which were not. However, the age-distribution of individuals listed as servants in census records suggest that the majority of servants in Northern Orkney were in fact young adults (Figure 1). We suspect that most of them corresponded to Hajnal's (1982:473) model of life-cycle service, but we cannot be certain.

\subsection{The Setting: Northern Orkney}

The northern Orkney Islands were overwhelmingly rural and agricultural during the period of interest (1851-1901). The economy of northern Orkney relied primarily on mixed agricultural production based on grains, mainly black oats and bere (a landrace of barley), root crops such as potatoes and turnips, and livestock including cattle, sheep, chickens, and pigs. These activities supported household subsistence and paid rents, often in kind. The institution of service has a long history in Orkney. It was well-established by the seventeenth century, when records show that there were 3-4 servants available to every 10 households (Flinn, et al., 1977), and it did not fully erode until the 1940s (Ewan, 2004; M. Gray, 1984), much later than in England.

Several characteristics of northern Orkney contributed to the staying power of service. Scottish agricultural practices, as necessitated by climate, differed from those in England. In England, agricultural improvements and rising wheat prices increased the size of holdings and the focus on wheat production, which requires intense, seasonal bursts of labor (Devine, 1984a). This restructuring of the agricultural sector meant that day laborers fit farmers' needs better than live-in servants (Cooper, 2005). Scottish agriculture, in contrast, was characterized by mixed farming (both arable and grazing) and different staple grains, namely

\footnotetext{
${ }^{3}$ It may be that some of these individuals were actually live-in servants who were at home rather than their place of employment on census night. Unfortunately, we cannot distinguish between temporary visits at home and full time residence. This may represent a source of bias in the sample of live-in servants.
} 
oats and bere instead of wheat (Fenton, 1997; Shaw, 1980). Pastoral and mixed agriculture was more conducive to live-in servants, as there was a more stable demand for labor yearround (Whittle, 2000). The importance of root crops, which require singling, hoeing, and so on, also demanded a steady supply of labor (Devine, 1984a). Relative to the mainland, Orkney had small, fragmented holdings with a large number of tenants, rather than owneroccupiers (Shaw, 1980). This probably also contributed to the maintenance of the practice of service, as it has been observed that servants persisted in areas with small holdings and disappeared when those holdings consolidated (M. Gray, 1984; Whyte \& Whyte, 1988).

\subsection{Households and Servants: The Decision to Hire}

Traditional farming systems, like that of nineteenth century Orkney, were characterized by reliance on human or animal traction, limited use of wage laborers, and household-level organization of production (Netting, 1993; Redfield, 1989; E. R. Wolf, 1966). The household, therefore, used the labor of its members to meet its consumption requirements. In this context of production organized at the household level, several factors potentially influenced a household's decision to hire a live-in servant. Perhaps among the most important was the age- and sex-composition of the household's members. Specifically, the number of people present in the household, and their age- and sex-composition relative to available productive resources such as land, would affect the household's need for additional labor. In his theory of the peasant economy, Chayanov (1986) noted that the balance of household workers relative to consumers is essential to understanding how families meet their needs, and that the ratio of age- and sex-weighted consumers to similarly weighted producers (the $\mathrm{C} / \mathrm{P}$ ratio) changes over the household life cycle. The household $\mathrm{C} / \mathrm{P}$ ratio is calculated by assigning each household member, including servants, a weight for their relative productive and consumptive capacities, summing those weights, and creating a ratio. In the weighting system employed in this study, a household that consists of a 30 year old male and 30 year old female would have a $\mathrm{C} / \mathrm{P}$ ratio as follows:

$$
(1.0+0.8) /(1.0+0.8)=1.0
$$

where the production and consumption weights for a 30 year old man are 1.0 and the production and consumption weights for a 30 year old woman are 0.8 .

Unfavorable household $\mathrm{C} / \mathrm{P}$ ratios have been found to have important effects, including increased risk of infant mortality (Campbell \& Lee, 1996; Sparks, 2007) and poor anthropometric measurements in children (Hagen, et al., 2006). Studies have observed changes in land use allocation over the household life cycle (Perz, 2003), and C/P ratios are predictive of the formation and dissolution of extended-family living arrangements (Jennings, 2010; Jennings et al., 2009). Given the importance of C/P ratios to various dimensions of the household economy and the demographic fortunes of households, it is hypothesized that the household $\mathrm{C} / \mathrm{P}$ ratio will be an important predictor of whether servants are present in households.

Measures other than C/P ratios can provide insight into aspects of household composition. The number of individuals present in the household may be an important predictor of the presence of servants, as crowded households may find it harder to provide space for live-in servants (assuming house size is held constant). The marital status of the household head may provide clues about the presence or absence of essential adult workers, as a single or widowed head of household would be "missing" the labor of a spouse, whose absence might be offset by hiring a servant. The sex balance of adults of working age is another measure of household composition that may relate to the demand for servant labor. As we define it, the worker sex ratio reflects the sex composition of household members of working age 
(arbitrarily set at 15-65 years) who are not servants, and is calculated by dividing the total number of working males aged 15-65 by the total number of workers of both sexes aged 15-65. If the worker sex ratio equals one, then all the non-servant household workers are male, and if the ratio equals zero, than all the non-servant workers are female. The worker sex ratio may determine whether households would have demand for additional laborers for sex-specific tasks. In addition, the age of the household head has been used as a proxy for stages in the household life cycle (Anderson, 1971; Katz, 1975; Sieder \& Mitterauer, 1983; A. P. Wolf, 1984). For example, young married heads would likely face a labor shortage, as their children are not yet old enough to work but must be supported from household production.

Finally, the kin relationships among the non-servant members of the household may indicate the diversity of the household labor force. Simple family households, consisting of a single married couple, or a surviving member of that couple, and their children, would have a less diverse labor force than an extended-family household, which includes one or more individuals in addition to the simple family household. A third, more complex, household type, typically not included in household classification systems, is found in Orkney. Using archaeological evidence, in tandem with written records, the North Orkney Population History Project has found that units listed separately in the census but that share a single farm name often operated as single economic entities (Jennings, 2010). The physical domiciles making up these "compound" households, often linked by brothers, are adjacent or even structurally joined and share a common set of farming structures such as barns, byres, grain kilns, and stables. Given what is known about Orcadian economic and social systems, the component units of compound households were probably not independent. Rather, they worked their landholdings cooperatively and shared the products of their labor, even if employed in outside wage labor, which was often part-time or seasonal. With respect to servants, there are competing hypotheses about the effects of household type. It is possible that compound (and possibly extended) households were less likely to hire servants, as their larger size and more complex kin organization might provide them with a larger and more diverse labor force, thereby decreasing the need for servant labor. However, compound households, which occupy larger structures that consist of more than one dwelling, could more easily house a servant. In addition, while a larger and more complex household might have a larger and more diverse labor force, it might also have more dependents, particularly children and the elderly, who need additional resources for their care, thus requiring additional labor.

Other factors may influence a household's decision to hire servants. One of these is access to land or, equivalently, the size of the household's landholding. Households with few laborers relative to land resources would be more likely to hire servants, whereas households with many laborers relative to their landholdings are less likely to require the additional labor provided by a servant. Information about the size of landholdings in north Orkney is taken from valuation rolls, which are listings of the taxable values of property that are closely related to the size of landholdings in acres of arable and pasture (for a detailed description and analysis of these records, see Jennings, 2010: Appendix A). In addition to the amount of land, households may also differ in their need for servant labor because of the specific tasks they need to accomplish. For example, labor-intensive farm work may require servant labor more than other occupations such as small-scale fishing, shopkeeping, or teaching. Thus, the occupation of the household head may be an important predictor of the number of servants present in the household.

\subsection{The Sexual Division of Agricultural Labor: Implications for Servants}

There is some debate in the literature concerning the extent of women's participation in agricultural labor in pre-modern Scotland (Devine, 1984b; M. Gray, 1984; Pinchbeck, 1969; 
Whittle, 2005). It is unclear whether male and female servants completed the same productive tasks, or if servants were hired for sex-specific work. The Orkney dataset provides information not only on the number of servants present in the household, but also on the sex of the servant. Certain household characteristics, indeed many of the same characteristics described above, might be differentially associated with the numbers of male versus female servants.

In rural districts throughout the British Isles during the preindustrial era, service was the most common employment for single women (Pinchbeck, 1969). Yet there has been some debate about the extent of female participation in agriculture (Whittle, 2005). Examples of tasks commonly described as women's work include dairying, poultry keeping, vegetable growing, brewing, baking, weeding, and harvesting (Whittle, 2000). In the context of Scottish agriculture, the hoeing of potatoes and turnips was a common (and onerous) female task (Pinchbeck, 1969). Despite these gendered activities, or the purported sexual division of labor, many studies note that female servants participated in a full range of farm work, both "in and out" of the house (M. Gray, 1984). Women apparently took part in every farm task, except perhaps the tending of horses (Devine, 1984b). Their work included the heaviest kinds of agricultural labor, such as plowing and harrowing (Pinchbeck, 1969). But certain tasks, especially tending turnips, dairying, and byre work, were dominated by women (Devine, 1984b). In other chores, most notably harvesting, men and women worked side-byside but in slightly different capacities. For example, harvesting using the sickle, a semicircular blade attached to a short handle, was acceptable for both sexes, but harvesting using the scythe, a long blade attached to a long handle, was solely the domain of men (Fenton, 1997; Howatson, 1984). In fact, the development and adaptation of heavier tools, such as the scythe, are said to be reflected in changes in the sexual division of labor (Snell, 1985).

Was the labor of male and female servants largely interchangeable, or did households hire a servant of a particular sex based on household composition or specific labor needs? Some evidence from the cottage textile industry in Ireland suggests that the hiring of female servants, who specialized in spinning, and male servants, who specialized in weaving, depended on the age- and sex-composition of the household, as well as how much yarn was bought rather than produced by the household (J. Gray, 2006). In addition, studies of English servants indicate that the sex composition and number of servants was determined by the status and occupation of the household head (Goldberg, 1992).

An examination of the sex-specific nature of live-in servants may provide insight into the agricultural and non-agricultural sectors of the rural economy in Orkney, as some households may require labor from servants of a particular sex. We hypothesize that the ageand sex-composition of the household, as measured by $\mathrm{C} / \mathrm{P}$ ratios or household types (simple, extended, or compound) will be important predictors of the presence of male or female servants. The worker sex ratio, another measure of household composition, may determine whether households chose to hire male or female servants in an effort to obtain a desired balance of male and female labor or provide a minimum number of workers of each sex. The occupation of the head may also be an important factor in the decision to hire sexspecific labor, as farmers might require more male labor (for plowing, for example), but tailors more female labor for tasks such as sewing and dressmaking. The amount of land to which a household has access may also be a determinant of the need for sex-specific labor, as land-rich households may need more field workers, but land-poor households may require more craft specialists. The sex and marital status of the household head may also be predictive of the sex of any servants present, as a female-headed households may prefer male labor to replace the labor of the absent (usually deceased) male head, while a household headed by a unmarried male may require the skills of a female servant. 


\section{Data}

Two primary data sources are used in this study: individual-level census returns and valuation rolls. These data were collected from the Orkney County Archive as part of an ongoing study of the population history of the northern Orkney Islands conducted by the North Orkney Population History Project (Murtha et al., 2008). The decennial censuses provide information on every person at home on the day of enumeration, including age, sex, relationship to the head, "occupation", and marital status. From these returns, servants are identified, and the composition of the household is obtained. The names of houses and farmsteads, which persist over time (Palsson \& Edwards, 1981; Thomson, 2008a, 2008b), are used to link the census returns to the valuation rolls, which are records of the taxable value of land. In all, 88 percent of households in the census and 85 percent of properties in the valuation rolls could be linked using farmstead names. The data used in the first and second parts of this study represent all households on the islands of Westray, Eday, Papa Westray, Sanday, North Ronaldsay, and Faray for which record linkage was possible.

It is important to note that our sampling method may introduce bias into the data. For instance, the village of Pierowall on Westray was excluded because linkage using house names was not possible, as households (particularly compound households) within Pierowall cannot be readily distinguished based on house names alone-that is, their sites have been so thoroughly built over that their archaeology is effectively invisible. In addition, small farmsteads, farmsteads that were abandoned early in the study period, and farmsteads that were infrequently occupied, are less likely to be linked using house names. These farmsteads might not appear in multiple records, the exact name and location of the farmstead may not be clear from historical maps or surface surveys, or the names could have been "forgotten" in the oral history of the islands. The sample drawn from this method consists of 2917 total observations of 664 households (as households can be observed over multiple census years). Table 1 details the number of households by census year.

Servants are observed at the time of each decennial census from 1851 to 1901 . Householdlevel predictor variables are taken from the census record of the household in which the servant was living at the time of the census. Variables related to the household head are calculated using census data listed for the head of household in which the servant resided. In the case of compound households, in which more than one head is listed for a single named farmstead, the mean of a particular variable is calculated. For example, if a compound household contained one male and one female head, the value of the variable for the sex of the head would be 0.5 . All continuous variables are centered on the mean.

Valuation rolls, linked to census data using farm names, list the taxable value of land and buildings, which has been shown to be a good proxy measure of landholding size and quality (Jennings, 2010). C/P ratios are calculated using the age- and sex-specific weights for production and consumption proposed by Hammel (2005). Households are coded for type using the definition of compound household developed for Orkney (namely the census listing of two or more household heads at a single named farmstead) along with the Hammel-Laslett classification system for non-compound households (Hammel \& Laslett, 1974; Jennings, 2010). Occupation variables were coded as farm-related (1) and not farmrelated (0) by members of the NOPH project. 4

\footnotetext{
${ }^{4}$ Farm occupations include farmer, agricultural laborer, ploughman, crofter, and so on. Non-farm occupations include, but are not limited to, fisherman, shop keeper, sailor and teacher. Individuals with two listed occupations, such as farmer and fisherman, are coded as farm occupations if at least one of listed occupations is farm-related.
} 


\section{Methods}

\subsection{Number of servants}

To determine which household-level variables are predictive of the number of servants present in the household, a hurdle regression model is fit to the data, with the number of household servants (including zero) as the outcome variable. Because the data are overdispersed, the hurdle model is preferred to a single Poisson model. The hurdle model is estimated in two steps (Mullahy, 1986; Cameron and Trivedi, 1998; Long and Freese, 2006). A logit model predicts zero counts, or whether a household does or does not have a servant. Once the "hurdle" of whether a servant is present is crossed, a zero-truncated Poisson model predicts non-zero counts, or the number of servants hired if a household has servants. Thus, the hiring of servants can be interpreted as a two stage process; first, the decision whether to hire a servant or not, and second, how many servants should be hired.

The frequency of live-in servants and the number of households that include them decrease over the study period, so a control for the effects of period is included. Models specified with a linear, rather than piecewise, function for time had lower Akaike Information Criteria (AIC), so the linear variable for census year is chosen. Households can appear in the sample in more than one census year, so standard errors are adjusted by clustering over a household identifier. A main effects model and models with household- and time-interaction terms are estimated. All models were estimated using STATA 11 SE (StataCorp, 2009).

\subsection{Number of servants by sex}

This portion of the study seeks to determine whether the labor of male and female servants is largely interchangeable, or if household-level characteristics can predict whether a household has additional male or female servants. To compare the effects of household-level characteristics on the number of servants by sex, two hurdle regression models are fit to the data, with the number of female servants present as the outcome variable in one model and the number of male servants present as the outcome variable in the other. To compare these two non-nested models, parameter estimates and covariance matrices are obtained from the two hurdle models separately and entered into a "seemingly unrelated regression" (SUR) model (Srivastava \& Giles, 1987). This procedure adjusts the estimated standard errors for the simultaneous estimation of two equations. With these adjustments, it is possible to conduct hypothesis tests of the coefficients across the two equations. For example, it is possible to test whether the estimated coefficient of household size in the male servants' equation is equal to the same coefficient in the female servants' equation. To conduct these comparisons, a series of Wald tests of linear hypotheses is performed. P-values were adjusted for multiple testing using the Bonferroni method. A main effects model and an interaction model with the same terms as the hurdle models for the total number of servants are presented to facilitate the comparison and interpretation of both portions of the study. Again, a linear variable is used to control for the effects of period, and robust standard errors are calculated by clustering over a household identifier.

\section{Results}

Servants make up a maximum of 8.8 percent of all the individuals included in the sample in 1851 and a minimum of 4.2 percent in 1901 (Table 2). Of the sample aged 12 to 30, a maximum 28 percent of individuals are servants in 1851 and a minimum 13 percent are servants in 1891 (Table 3). These findings are consistent with other studies of the frequency of servants in Northwest Europe (Anderson, 1971; Laslett, 1997, 2000;Kussmaul, 1981a). The sex composition of servants is roughly equal, although females usually outnumber males and tend to be 1-2 years older than their male counterparts (Table 4). The observed 
age distribution of servants is consistent with service as a life-cycle occupation rather than a permanent one (Figure 1).

\subsection{Number of servants}

The results of the hurdle regression models are presented in Table 5. The full model, which includes both household-level and time interactions, fits better than the main effects model according to the AIC and a likelihood ratio test $\left(\chi^{2}(10)=118.52, p<0.0001\right.$, main effects versus full model). Likelihood ratio tests of the full model versus models with householdlevel interactions or time interactions only also indicate that the full model has better fit. In the main effects model, terms associated with household-level variables have significant effects in both the logit and Poisson steps. In the logit step, households with servants have lower (more favorable) C/P ratios, higher valuation, slightly higher household size, and a higher worker sex ratio than household that do not have servants. Household type, or whether the household is compound, extended, or simple, and most of the variables related to the household head are not associated with the presence of servants in the logit step. However, the marital status of the head is important, as single or widowed heads are more likely to hire servants than married heads. In the Poisson step, which accounts for the number of servants present among those households that have at least one servant, all but one of the significant covariates in the logit model remain significant. The worker sex ratio is no longer a significant predictor of the number of servants present, and the effects of valuation and household size have decreased.

Pairwise interaction terms for valuation, household size, and $\mathrm{C} / \mathrm{P}$ ratio were added to the main effects model. Earlier studies of the formation and dissolution of households found these terms to be important (Jennings et al., 2009). In addition, the interactions of these variables are related to the balance of household labor and land resources, which is likely to influence the demand for servant labor. In addition, the number of servants in the population and several other variables, including household size, change over time, so the interaction of several predictor variables and time were tested. In the full model, which includes all interaction terms, the coefficients for the interaction of household size and valuation and household size and time are significant in both steps of the model, while the marital status of the head becomes is now only bordering on statistical significance. In the Poisson step of the full model, male-headed households are more likely to include additional servants.

\subsection{Number of servants by sex}

The results of the hurdle regression models of the number of servants by sex, adjusted using SUR, are presented in Tables $6 \mathrm{a}$ and $6 \mathrm{~b}$, and the results of the Wald tests of the equality of coefficients across equations are shown in Table 7. In the logit portion of the main effects model, the coefficients of the $\mathrm{C} / \mathrm{P}$ ratio, worker sex ratio, and occupation of the head are not equal in the equations for the number of male servants versus female servants. Households that include at least one male servant have lower $\mathrm{C} / \mathrm{P}$ ratios than households that do not hire male servants. However, in the case of female servants, households that include a female servant do not have significantly different $\mathrm{C} / \mathrm{P}$ ratios than households that do not include female servants. Households with a lower worker sex ratio (more females than males) are more likely to include at least one male servant and households with a higher worker sex ratio are more likely to include at least one female servant. If a household head is a farmer, the household is more likely to include at least one male servant, while if the household head is not a farmer, the household is more likely to include at least one female servant. A similar pattern holds for the logit portion of the interaction model. However, in the Poisson portions of both the main effects and interaction models, none of the coefficients are significantly different between the male and female models (Table 7). This suggests that among 
households that have at least one servant, household- and head-related variables are not important determinants of the sex of additional servants hired.

\section{Discussion}

These results have implications for the study of servants and their importance to the household and rural economy. Several household-level predictors are significantly associated with the number of servants. These include $\mathrm{C} / \mathrm{P}$ ratio, valuation (a proxy for the size of landholding), household size, worker sex ratio, the occupation of the head, and the marital status of the head as well as interactions among valuation and household size. Households that hire servants have lower $\mathrm{C} / \mathrm{P}$ ratios than households that do not, and among those households with servants, households with greater numbers of servants have lower $\mathrm{C} / \mathrm{P}$ ratios than households with fewer servants. This is not an unexpected finding, as servants are included in the calculation of $\mathrm{C} / \mathrm{P}$ ratios, and the addition of young adult laborers to a household should improve the balance of producers to consumers. Unfortunately, because the precise timing of the hiring of any particular servant cannot be determined using the available data, we are unable to discern whether households with more favorable C/P ratios are more likely to hire servants or if households that hire servants do so to in an effort to improve an unfavorable $\mathrm{C} / \mathrm{P}$ ratio. Households with higher valuations are positively associated with the presence of servants in both the logit and Poisson steps of the model. This suggests that there is greater demand for servant labor among households with access to higher valued holdings. Finally, the effect of marital status of the head on the presence or number of servants implies that servants can, and least in part, serve as a replacement for the labor usually filled by a spouse. The significance of time and household-level interactions suggests that the relationships among servants, households, and land are complicated and change over time. Future studies, especially those that consider land use explicitly, may be better able to parse out these relationships.

An interesting negative finding relates to predictor variables reflecting the status of the household head. The age, sex, and occupation of the head were not significantly associated with the presence or number of servants in the household after controlling for other factors. These results run somewhat counter to predictions about headship, especially the age of the head, which is usually thought to correspond to stages in household Chayanovian cycles (Anderson, 1971; Katz, 1975; Sieder \& Mitterauer, 1983; A. P. Wolf, 1984). In addition, one might predict that female-headed households face labor shortages, especially given that that men tend to be listed as head except in cases where the husband is dead or the woman was never married. Therefore, the presence of a widowed female head probably indicates that an adult laborer (the dead husband) has been lost from the household. However, it may be that other household members, such as older children and other kin, make up for the lost labor of the missing husband. There did not seem to be an important "widowed head" effect. An interaction term for unmarried female heads was added to each of the models, but the estimated coefficients of the sex of the head and marital status of the head did not change appreciably and the interaction term was not significant. Another noteworthy negative finding is the non-significance of household type. In this case, the different structure of the three household type categories may be accounted for in the $\mathrm{C} / \mathrm{P}$ ratio.

The results of the models related to the sex of servants have implications for the debate about the nature of the sexual division of rural labor. The coefficients for $\mathrm{C} / \mathrm{P}$ ratio, valuation, worker sex ratio, and occupation of the head were different between the two equations only in the logit portion of the hurdle model. Thus, household predictors in the sex-specific models were only different between households that have at least one servant and households that have no servants. Among households with servants, the effects of household-level covariates were essentially the same for both males and females. These 
results suggest that the specific sex of the servant hired is an important consideration for households as they choose whether or not to hire any servants, but not in the case of households that have one servant or more.

In the logit step of the main effects and interaction models, households that include a male servant have lower $\mathrm{C} / \mathrm{P}$ ratios than households that do not, and the coefficients for $\mathrm{C} / \mathrm{P}$ ratio is significantly lower than those in the female-only models. Households appear to hire servants in response to worker sex ratios, as households with higher ratios (more nonservant males relative to non-servant females) hire more female servants and households with lower ratios hire more male servants. The term for valuation in the logit step of the hurdle model is significantly larger for males than females, suggesting that there may have been a higher "threshold" for valuation when it came to hiring the first female servant than the first male servant. Holding other factors constant, non-farming heads were more likely to hire female servants than farming households, who were more likely to hire males. This finding lends support to the notion that the sexual division of labor operated differently among the farming and non-farming segments of the rural economy. Some female servants were probably domestic workers (e.g. housemaids, child carers, or cooks) or craft specialists (e.g. spinners or weavers) rather than agricultural laborers. These female servants may also have worked to perform other domestic tasks for everyone present in the household, including male servants. These findings support the premise that male and female labor was not fungible, but rather that the sexes engaged in different forms of labor, although certain tasks may have overlapped. Households may seek a desired balance of male and female workers, as evidenced in the differential effects of household worker sex ratio. Alternately, there may be a minimum number of males and females required to operate a holding and households hired servants to meet this minimum.

While this study cannot settle the precise role of live-in servants as part of an "adaptive family economy" (Wall, 1986), the strength and significance of several household-level and head-related variables as predictors of both the general and sex-specific models demonstrate the important effects that servants can have on the household economy. In addition, the significance of several interaction variables suggests that these relationships are not simple. Future work in this area might examine the relationships between the source and service households of servants using more completely linked data or using a different data source with more detail about the timing of an individual's entrance and exit from service.

\section{Acknowledgments}

We acknowledge the support of the National Science Foundation (HSD052739), Eunice Kennedy Shriver National Institute of Child Health and Human Development (T32 HD007514, T32 HD07168), the Pennsylvania State University Department of Anthropology, the Pennsylvania State University Population Research Institute, and the Carolina Population Center at the University of North Carolina at Chapel Hill. We also thank Tim Murtha, Corey Sparks, Kenneth Hirth, Duane Alwin, Stephen Matthews, Debashis Ghosh, Paul Leslie, Leah Boustan, and two anonymous reviewers for their thoughtful comments on earlier drafts of this paper.

\section{References}

Anderson, M. Family Structure in Nineteenth Century Lancashire. Cambridge: Cambridge University Press; 1971.

Cameron, AC.; Trivedi, PK. Regression Analysis of Count Data. New York: Cambridge Press; 1998.

Campbell C, Lee JZ. A death in the family: Household structure and mortality in rural Liaoning: Lifeevent and time-series analysis, 1792-1867. The History of the Family. 1996; 1:297-328. [PubMed: 12347666]

Chayanov, AV. The Theory of Peasant Economy. Madison: University of Wisconsin Press; 1986. 
Cooper SMI. Service to servitude? The decline and demise of life-cycle service in England. The History of the Family. 2005; 10:367-386.

Devine, TM. Introduction: Scottish farm service in the Agricultural Revolution. In: Devine, TM., editor. Farm Servants and Labour in Lowland Scotland, 1770-1914. Edinburgh: John Donald; 1984a. p. 1-9.

Devine, TM. Women workers, 1850-1914. In: Devine, TM., editor. Farm Servants and Labour in Lowland Scotland, 1770-1914. Edinburgh: John Donald; 1984b. p. 98-123.

Engelen, T.; Wolf, AP. Marriage and the Family in Eurasia: Perspectives on the Hajnal Hypothesis. Amsterdam: Askant; 2005.

Ewan, E. Mistresses of themselves? Female domestic servants and by-employments in sixteenth century Scottish towns. In: Fauve-Chamoux, A., editor. Domestic Service and the Formation of European Identity. New York: Peter Lang; 2004. p. 411-434.

Fauve-Chamoux, A., editor. Domestic Service and the Foundation of European Identity: Understanding the Globalization of Domestic Work, $16^{\text {th }}-21^{\text {st }}$ Centuries. New York: Peter Lang; 2004.

Fenton, A. The Northern Isles: Orkney and Shetland. East Linton, Scotland: Tuckwell Press; 1997.

Flinn, MW.; Gillespie, J.; Hill, N.; Maxwell, A.; Mitchison, R.; Smout, C. Scottish Population History: From the 17th Century to the 1930s. Cambridge: Cambridge University Press; 1977.

Goldberg, PJP. Women, Work, and Life Cycle in a Medieval Economy: Women in York and Yorkshire c. 1300-1520. New York: Oxford University Press, USA; 1992.

Gray J. Gender composition and household labour strategies in pre-Famine Ireland. The History of the Family. 2006; 11:1-18.

Gray, M. Farm workers in North-east Scotland. In: Devine, TM., editor. Farm Servants and Labour in Lowland Scotland. Edinburgh: John Donald; 1984. p. 10-28.

Hagen EH, Barrett HC, Price ME. Do human parents face a quantity-quality tradeoff?: Evidence from a Shuar community. American Journal of Physical Anthropology. 2006; 130:405-418. [PubMed: 16365856]

Hajnal J. Two kinds of preindustrial household formation systems. Population and Development Review. 1982; 8:449-494.

Hammel EA. Chayanov revisited: A model for the economics of complex kin units. Proceedings of the National Academy of Sciences. 2005; 102:7043-7046.

Hammel EA, Laslett P. Comparing household structure over time and between cultures. Comparative Studies in Society and History. 1974; 16:73-109.

Howatson, W. Grain harvesting and harvesters. In: Devine, TM., editor. Farm Servants and Labour in Lowland Scotland, 1770-1914. Edinburgh: John Donald; 1984. p. 124-142.

Jennings, JA. Household Structure, Dynamics, and Economics in a Preindustrial Farming Population: The Northern Orkney Islands, Scotland, 1851-1901. Unpublished Dissertation. University Park, PA: The Pennsylvania State University; 2010.

Jennings, JA.; Sparks, CS.; Wood, JW.; Johnson, PL.; Murtha, TM.; Matthews, SA. Formation and dissolution of extended-family households in Orkney, Scotland, 1851-1901. Presented at the Meeting of the International Union for the Scientific Study of Population; Marrakech, Morocco. 2009.

Katz, MB. The People of Hamilton, Canada West: Family and Class in a Mid-nineteenth-Century City. Cambridge: Harvard University Press; 1975.

Kussmaul, AS. Servants in Husbandry in Early Modern England. Cambridge: Cambridge University Press; 1981a.

Kussmaul AS. The ambiguous mobility of farm servants. The Economic History Review. 1981b; 34:222-235.

Laslett, P. Family Life and Illicit Love in Earlier Generations: Essays in Historical Sociology. New York: Cambridge University Press; 1977.

Laslett, P. The World We Have Lost: Further Explored. London: Routledge; 2000.

Long, S.; Freese, J. Regression Models for Categorical Dependent Variables using STATA. College Station, TX: STATA Press; 2006. 
Mullahy J. Specification and testing of some modified count data models. Journal of Econometrics. 1986; 33:341-365.

Murtha, TM.; Johnson, PL.; Wood, JW.; Matthews, SA.; Sparks, CS.; Jennings, JA. Historical demography, oral history, settlement archaeology, and landscape ecology: The North Orkney Population History Project. Presented at the annual meeting of the European Population Conference; Barcelona, Spain. 2008.

Netting, RM. Smallholders, Householders: Farm Families and the Ecology of Intensive, Sustainable Agriculture. Stanford: Stanford University Press; 1993.

Oris M. The history of migration as a chapter in the history of the European rural family: An overview. History of the Family. 2003; 8:187-215.

Palsson, H.; Edwards, P. Orkneyinga Saga: The History of the Earls of Orkney. London: Penguin Books; 1981.

Perz SG. Household demography and land use allocation among small farms in the Brazilian Amazon. Human Ecology Review. 2003; 9:1-16.

Pinchbeck, I. Women Workers and the Industrial evolution, 1750-1850. London: Virago; 1969.

Redfield, R. The Little Community and Peasant Society and Culture. Chicago, IL: University of Chicago Press; 1989.

Reher DS. Family ties in Western Europe: Persistent contrasts. Population and Development Review. 1998; 24:203-234.

Shaw, FJ. The Northern and Western Islands of Scotland: Their economy and society in the seventeenth century. Edinburgh: John Donald; 1980.

Sieder, R.; Mitterauer, M. Wall, R.; Robin, J.; Laslett, P. Family Forms in Historic Europe. Cambridge: Cambridge University Press; 1983. The reconstruction of the family life course: theoretical problems and empirical results; p. 309-346.

Snell, KDM. Annals of the Labouring Poor: Social Change and Agrarian England, 1660-1900. Cambridge: Cambridge University Press; 1985.

Sparks, CS. Households, Land, and Labor: Population Dynamics in the Northern Orkney Islands, Scotland, 1851 to 2003. Unpublished Dissertation. University Park: The Pennsylvania State University; 2007.

Srivastava, V.; Giles, D. Seemingly Unrelated Regression Equations Models: Estimation and Inference. New York: CRC Press; 1987.

StataCorp. Stata Statistical Software, Release 11. College Station, TX: StataCorp LP; 2009.

Thomson, WPL. The New History of Orkney. 3rd Ed. Edinburgh: Birlinn Ltd.; 2008a.

Thomson, WPL. Orkney Land and People. Kirkwall: The Orcadian Limited Kirkwall Press; $2008 b$.

Viazzo PP, Aime M, Allovio S. Crossing the boundary: Peasants, shepherds, and servants in a western Alpine community. The History of the Family. 2005; 10:387-405.

Wall, R. Work, welfare, and the family: An illustration of the adaptive family economy. In: Bonfield, L.; Smith, RM.; Wrightson, K., editors. The World We Have Gained: Histories of Population and Social Structure. New York: Basil Blackwell; 1986. p. 261-294.

Watson, J. The Annals of a Quiet Valley, by a Country Parson. London: J. M. Dent; 1894.

Whittle, J. The Development of Agrarian Capitalism: Land and Labour in Norfolk, 1440-1580. New York: Oxford University Press, USA; 2000.

Whittle, J. Servants in rural England c. 1450-1650: Hired work as a means of accumulating wealth and skills before marriage. In: Agren, M.; Erickson, AL., editors. The Marital Economy in Scandinavia and Britain, 1400-1900. Burlington, VT: Ashgate; 2005. p. 89-110.

Whyte, ID.; Whyte, KA. Leneman, L. Perspectives in Scottish Social History: Essays in Honour of Rosalind Mitchison. Aberdeen: Aberdeen University Press; 1988. The geographical mobility of women in early modern Scotland; p. 83-106.

Wolf, AP. Family life and the life cycle in rural China. In: Netting, RMC.; Wilk, R.; Arnould, E., editors. Households: Comparative and Historical Studies of the Domestic Group. Berkeley: University of California Press; 1984. p. 279-298.

Wolf, ER. Peasants. Englewood Cliffs: Prentice-Hall; 1966. 


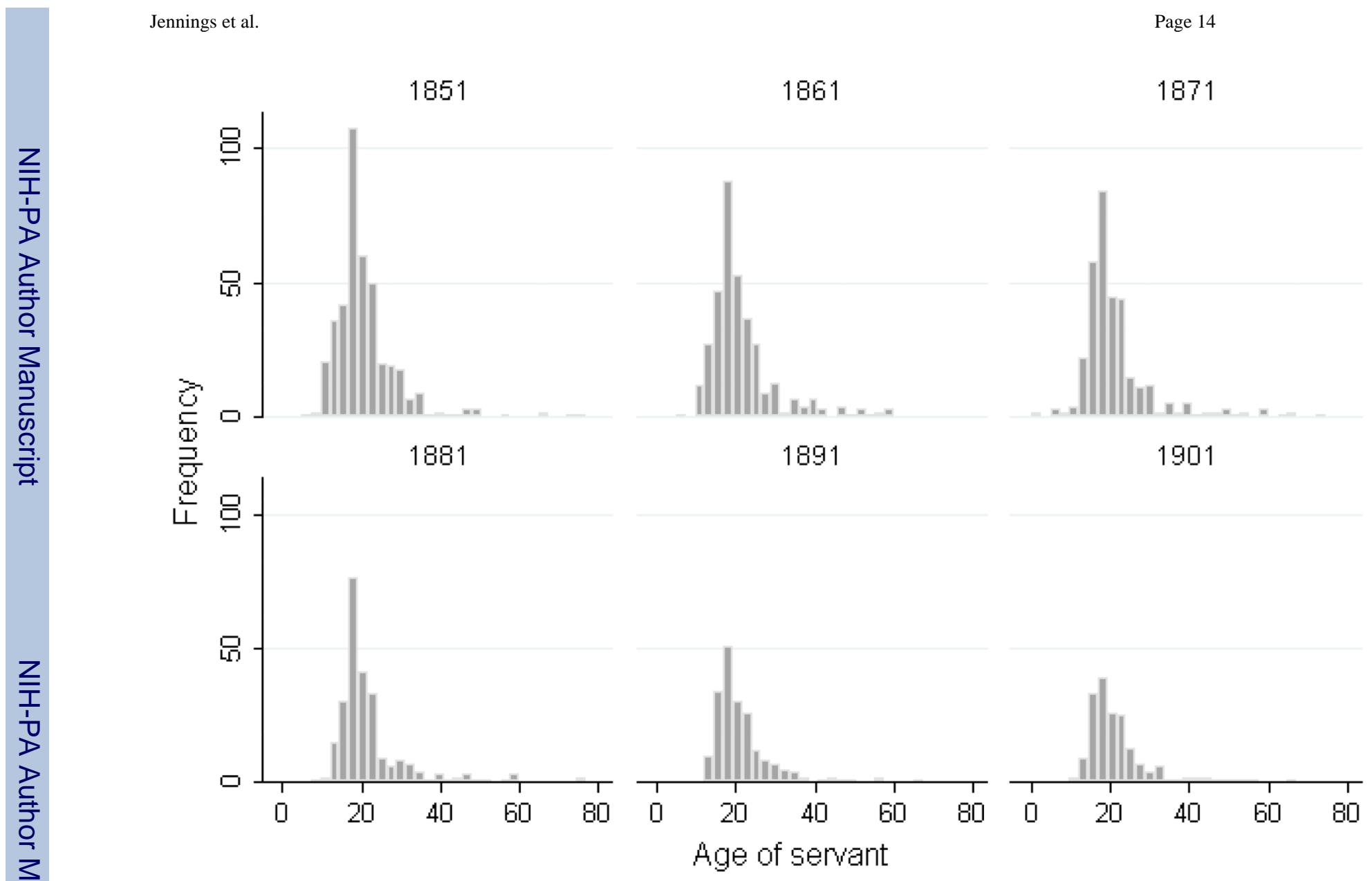

Figure 1.

Age distribution of servants by census year. 


\section{Table 1}

Number of households in the sample by census year and presence of servants.

\begin{tabular}{cccc}
\hline $\begin{array}{c}\text { Census } \\
\text { year }\end{array}$ & $\begin{array}{c}\text { Households } \\
\text { without } \\
\text { servants }\end{array}$ & $\begin{array}{c}\text { Households } \\
\text { with at least } \\
\text { 1 servant }\end{array}$ & Total \\
\hline 1851 & 432 & 167 & 599 \\
1861 & 469 & 157 & 626 \\
1871 & 487 & 163 & 650 \\
1881 & 545 & 140 & 685 \\
1891 & 534 & 117 & 651 \\
1901 & 544 & 104 & 648 \\
\hline
\end{tabular}


Table 2

Sample by census year.

\begin{tabular}{ccccc}
\hline Year & Non-Servants & Servants & Total & Percent Servants \\
\hline 1851 & 4646 & 409 & 5055 & 8.80 \\
1861 & 4902 & 351 & 5253 & 7.16 \\
1871 & 4957 & 334 & 5291 & 6.74 \\
1881 & 5099 & 250 & 5349 & 4.90 \\
1891 & 4611 & 197 & 4808 & 4.27 \\
1901 & 4222 & 178 & 4400 & 4.22 \\
\hline
\end{tabular}

Hist Fam. Author manuscript; available in PMC 2012 August 18. 
Table 3

Individuals of typical service age (12-30) in the sample.

\begin{tabular}{cccc}
\hline Year & Non-Servants & Servants & Percent Servants \\
\hline 1851 & 1261 & 351 & 27.84 \\
1861 & 1325 & 298 & 22.49 \\
1871 & 1308 & 284 & 21.71 \\
1881 & 1449 & 214 & 14.77 \\
1891 & 1290 & 173 & 13.41 \\
1901 & 1105 & 155 & 14.03 \\
\hline
\end{tabular}

Hist Fam. Author manuscript; available in PMC 2012 August 18. 
Table 4

Number and average age of servants by sex and census year.

\begin{tabular}{ccccc}
\hline Census Year & Males & $\begin{array}{c}\text { Mean Age of } \\
\text { Males }\end{array}$ & Females & $\begin{array}{c}\text { Mean Age of } \\
\text { Females }\end{array}$ \\
\hline 1851 & 207 & 19.42 & 202 & 22.99 \\
1861 & 164 & 20.89 & 187 & 22.77 \\
1871 & 150 & 20.97 & 184 & 22.47 \\
1881 & 112 & 20.97 & 138 & 23.39 \\
1891 & 87 & 21.23 & 110 & 22.19 \\
1901 & 91 & 21.60 & 87 & 22.52 \\
\hline
\end{tabular}

Hist Fam. Author manuscript; available in PMC 2012 August 18. 


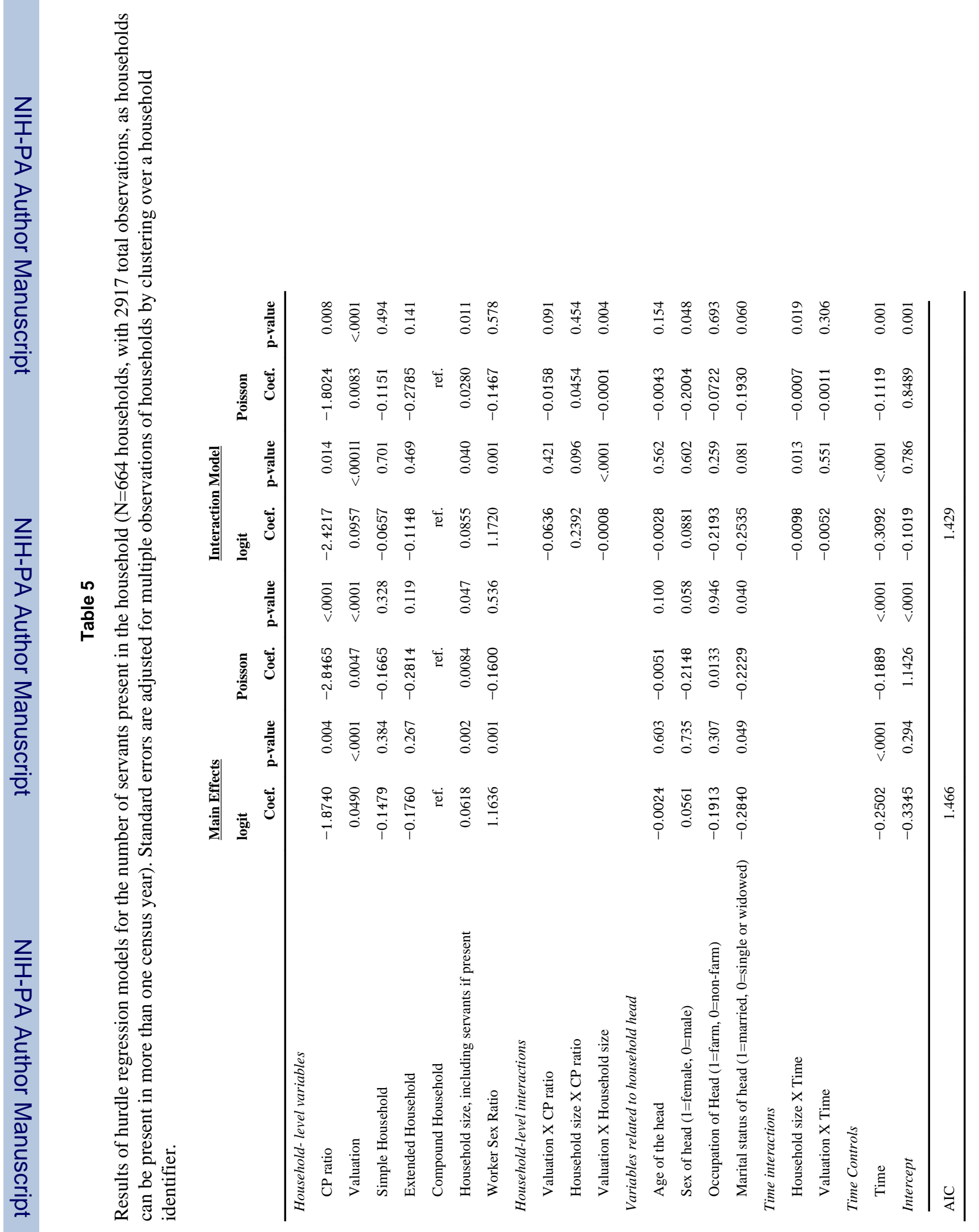




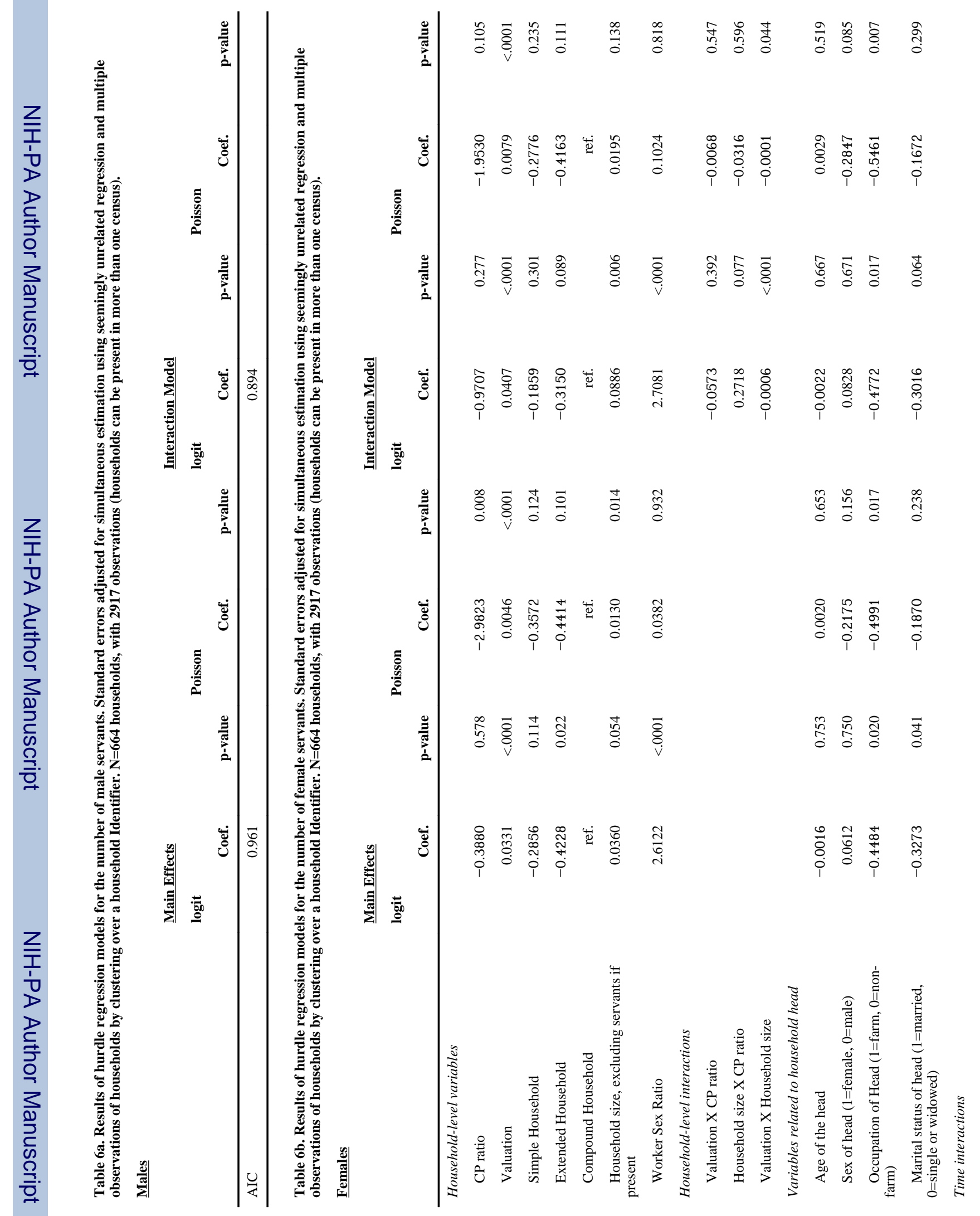




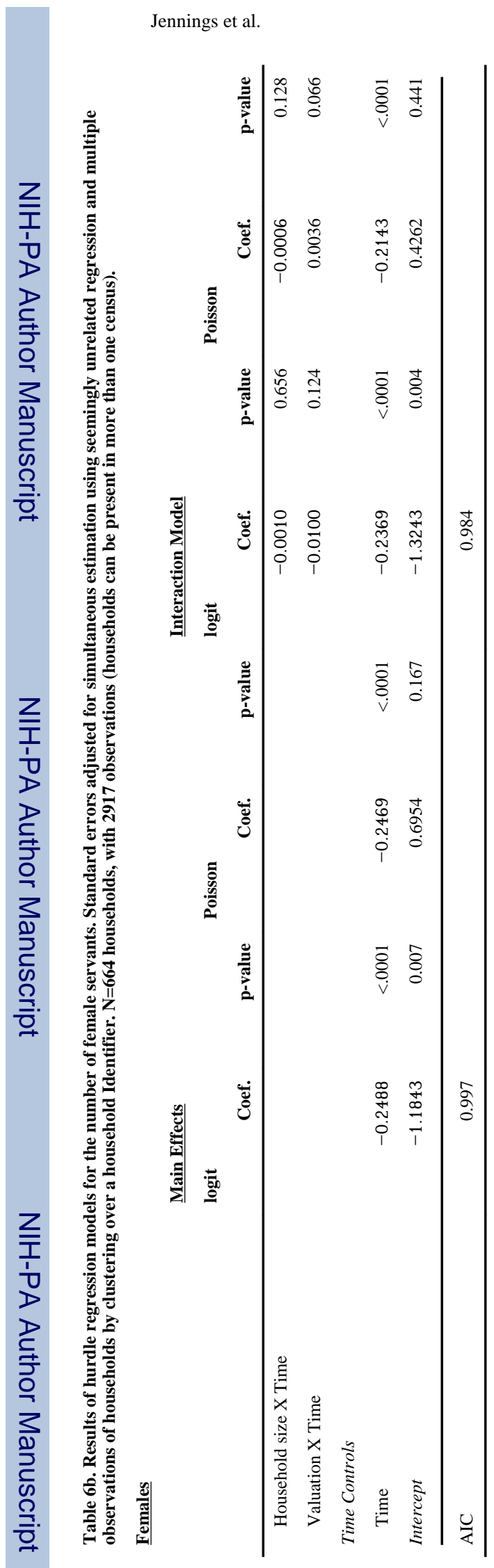

Hist Fam. Author manuscript; available in PMC 2012 August 18. 


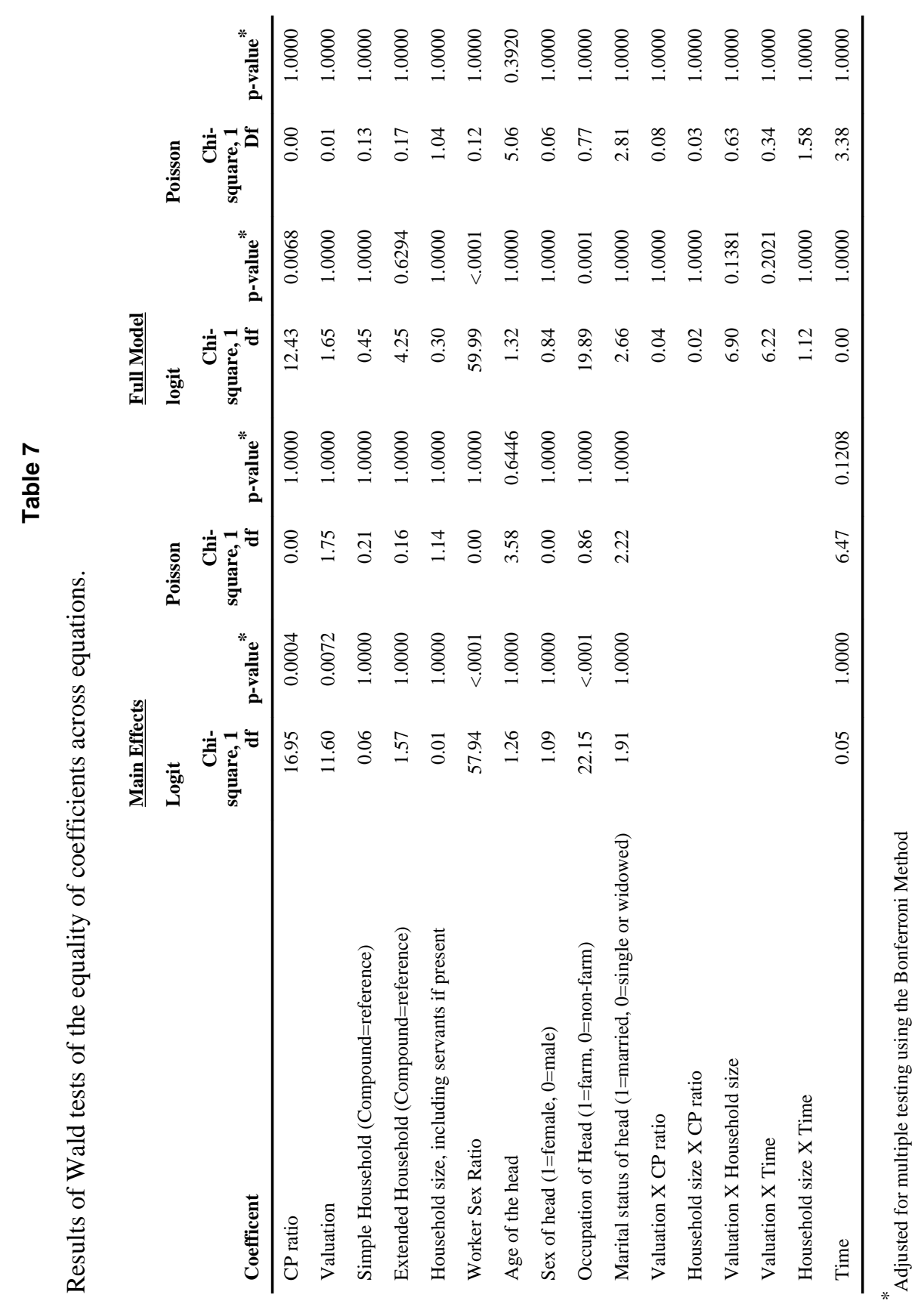

Hist Fam. Author manuscript; available in PMC 2012 August 18. 